\title{
MichaŁ DĄBROWSKI
}

INTERDYSCYPLINARNE STUDIA DOKTORANCKIE

SzkoŁa Wyższa Psychologir SpoŁecznej w Warszawie

E-MAIL:DEMIC82@GMAIL.COM

\section{ZMIANA NORMY PRAWNEJ \\ A PROCES INSTYTUCJONALIZACJI PRZEKRACZANIA GRANICY PAŃSTWOWEJ}

\section{Wstęp}

Analizując przestrzeń przejścia granicznego wraz z jego najbliższym otoczeniem można łatwo zaobserwować wiele innowacyjnych zachowań jednostek, które stale użytkują wspomniany obszar. Wiele tych działań jawi się jako chaotyczne, czy wręcz absurdalne. Jednakże długotrwała obserwacja pozwala stwierdzić, że rządzą się one logicznymi prawami. Proces wytworzenia ładu społecznego jest długotrwały. Nie jest on ustanowiony raz na zawsze, lecz ulega ciągłym dookreśleniom. Rzeczywistość przejścia granicznego nie tworzy się z niczego. Prawodawcy dwóch sąsiadujących krajów podsuwają gotowy model reguł przekraczania granicy. Jest w nim zapisane kto, na jakich warunkach, gdzie i jak często może wjechać do państwa ościennego. Działające jednostki często nad te reguły przedkładają własne interesy. Postępują zgodnie z własną logiką, która może być sprzeczna $\mathrm{z}$ interesem kraju. Państwo musi zmierzyć się z problemem nagminnego nieprzestrzegania prawa. Wprowadza bardziej rygorystyczne kontrole, zaostrza sankcje lub też wprowadza nowe normy, które w prostszy sposób będą mogły być egzekwowane. Zmiana przepisów zawsze powoduje wprowadzenie nowych reguł gry w rzeczywistości granicznej. Burzy nomos, czyli sens wytworzonego przez działające jednostki własnego świata. Jednakże trudno wyobrazić sobie, że rozwiąże od razu wszystkie problemy, które stały u podstaw wprowadzenia nowego prawa. Niemożliwe wydaje się również, że wyeliminuje ze społecznej rzeczywistości wszystkie niepożądane aktywności.

Celem artykułu jest zaprezentowanie wpływu zmiany przepisów dotyczących przekraczania granicy na zachowanie członków zbiorowości społecznej, którzy z przyjazdów do kraju sąsiedniego stworzyli stałe źródło dochodów. 
To właśnie zmiana reguł gry jest bezpośrednio w nich wymierzona. Jednak omawiana społeczność charakteryzuje się ponadprzeciętnym poziomem innowacyjności, co sprawia, że dosyć szybko znajduje pole do dalszej aktywności.

\section{Źródła inspiracji}

Inspiracją do napisania pracy był szok kulturowy ${ }^{1}$, którego doświadczyłem podczas przejścia ze świata własnej rzeczywistości społecznej do przestrzeni, która funkcjonuje zgodnie z zasadami kultury granicy. Poznanie logiki praw zachodzących na transgraniczu może być użyteczne do zwalczenia socjopatologii, która ma miejsce na nadgraniczu. Taką rolę uprawiania socjologii uważam za cenną dla środowiska praktyków społecznych.

Przedmiotem analizy czynię zjawiska, które zaobserwowałem po wprowadzeniu przez władze Białorusi ograniczeń w wywozie takich artykułów, jak: paliwo i papierosy ${ }^{2}$. Nowe przepisy zaburzyły w znacznym stopniu praktyki społeczne na przejściu granicznym.

Głównym celem pracy jest zaprezentowanie mechanizmów wpływających na zachowanie jednostek, które w wyniku wprowadzonej nowelizacji miały zostać wyeliminowane z przestrzeni granicznej.

Fundamentem do napisania niniejszego artykułu były badania przeprowadzone w ramach projektu „Kultura granicy - interdyscyplinarna analiza zjawisk społecznych zachodzących w obrębie przejścia granicznego w Kuźnicy”. Główną metodą, jaką zastosowano do eksploracji obszaru będącego źródłem inspiracji naukowej, była obserwacja ukryta uczestnicząca. Autor przeprowadzał ją osobiście w latach 2009-2012. Dodatkowym materiałem badawczym były wywiady przeprowadzone z ekspertami codzienności granicznej, czyli funkcjonariuszami Służby Celnej i Straży Granicznej, osobami zajmującymi się handlem przygranicznym, kierowcami ciężarówek, mieszkańcami miejscowości przygranicznych. Dostęp do unikalnego materiału badawczego zawdzięczam również temu, iż od 2008 roku jestem funkcjonariuszem Służby Celnej pełniącym obowiązki w granicznym oddziale celnym. Sposób prowadzonych przeze mnie badań jest zgodny z zaproponowanymi przez Koneckiego [1992] i Miszewskiego [2005]. Podobnie jak oni, staram się być

1 O szoku kulturowym, który związany jest z doświadczaniem wielu rzeczywistości społecznych pisali m.in. Berger i Luckmann. Zob. [Berger, Luckmann 1983: 52].

2 Zakaz dotyczył wywozu artykułów gospodarstwa domowego (płyt gazowych i elektrycznych, lodówek, zamrażarek), niektórych produktów spożywczych (kasza, makaron) oraz budowlanych (cement). Jednakże nie były one w analizowanym okresie przywożone do Polski. 
w środku wydarzeń i dzięki temu docieram do zjawisk i obszarów, które są trudno dostępne dla badaczy. Jednakże moja rola w społeczności ludzi granicy spowodowała, że prowadzona przeze mnie obserwacja czasami przypominała tę wykonaną przez Rottenburga [2000: 87-100] w słubickim barze na pograniczu polsko-niemieckim. Nie mogłem wszystkich faktów doświadczyć osobiście lub z pierwszej ręki, o części z nich dowiedziałem się z przekazu moich respondentów.

Główną inspiracją teoretyczną do wyjaśnienia analizowanego fenomenu były prace Schutza [2008], Bergera i Luckmanna. Siatka pojęciowa zaproponowana bądź też używana przez tych klasyków tradycji interakcyjno - fenomenologicznej w socjologii jest podstawą moich rozważań przeniesionych na grunt przejścia granicznego.

\section{Działanie, wiedza, codzienność}

Aktywność człowieka powoduje, że tworzy się świat społeczny. Efekt działalności ludzkiej jest dostępny zarówno dla jego twórcy, jak i osób, które znajdują się w jego otoczeniu. W naturę członków społeczeństwa wpisana jest kreatywność. Świat wytworzony przez człowieka jest otwarty na jego aktywność. Subiektywne czynności ludzkie, które są podzielane przez inne osoby najpierw stają się intersubiektywne, a z czasem, gdy wiedza o nich zostaje przekazana zaczynają być obiektywne. Zgadzam się z Zemło, iż Berger i Luckmann uważają, że cały społeczno - kulturowy wymiar świata jest wyłącznie produktem człowieka. Nieustannie wychodzące w świat zewnętrzny ludzkie aktywności wytwarzają go, utrwalają i nieprzerwanie zmieniają, wprowadzając nowe elementy i charakterystyki [Zemło 2003: 254].

Jednostki w swoim postępowaniu kierują się zasadą ekonomizacji podjętych czynności. Działanie, które przyniosło oczekiwany skutek staje się sposobem na rozwiązanie określonej sytuacji. Tym samym człowiek, swoją potencjalnie różnorodną aktywność, zawęża do jednego, dobrze znanego sposobu. Początkowo intencjonalne zachowanie przeradza się w wiedzę. W społecznym zasobie wiedzy szczególne miejsce zajmuje ta, którą Berger i Luckmann określają jako „wiedzę o charakterze przepisu”. Definiują ją jako ograniczoną do znajomości skutecznych sposobów postępowania, ułatwiających wykonywanie zwykłych czynności. Wiedza dostarcza członkom społeczności schematów typizujących, którą są niezbędne dla większości zrutynizowanych czynności, które wykonywane są w życiu codziennym. Typizacje dotyczą nie tylko in- 
nych osób, ale także wszelkiego rodzaju zdarzeń, zarówno o charakterze społecznym jak i odnoszących się do zjawisk przyrodniczych [Berger, Luckmann 1983: 79-80]. Ludzka aktywność zaczyna być nawykowa. Jednostki mogą również wiedzę o danym zachowaniu czerpać nie z własnych doświadczeń a w formie naśladownictwa. Wiedzę w społeczeństwie reguluje zasada istotności. Jest ona wyznaczana przez interes jednostki bądź pozycję w zbiorowości. Zasób mądrości społecznej nie jest równomiernie podzielany przez ludzi. Dla jednej osoby dane informacje będą czysto abstrakcyjne, wręcz bezużyteczne, $\mathrm{z}$ kolei dla innych jest to wiedza, którą wykorzystują w swojej codziennej aktywności.

Według Bergera i Luckmanna [1983: 52] wśród wielu rzeczywistości, ta dotycząca życia codziennego jest uprzywilejowana i powinna być uznana za podstawową. Autorzy twierdzą, że jest ona postrzegana jako uporządkowana. Jej zjawiska są ujęte we wzory, które jawią się jako niezależne od tego, czy są przez jednostki postrzegane [Berger, Luckmann 1983: 53]. Przez członków społeczności rzeczywistość życia codziennego jest przyjmowana bez zastrzeżeń. Jest to świat, który jest dzielony z innymi jednostkami. Oczywistość codzienności trwa dopóki nie przerwie jej pojawienie się problemu.

\section{Proces instytucjonalizacji na przejściu granicznym}

Człowiek, podczas swojej aktywności, dąży do wykreowania porządku społecznego. Dlatego też ważne jest utworzenie w społeczności instytucji, które będą odpowiadały za podtrzymywanie ładu społecznego. Instytucje w zbiorowości są to sposoby rozwiązywania problemów, jest to też forma uregulowanej działalności ludzkiej. Z pozoru chaotyczne działanie ludzkie wytwarza sieć instytucji, dzięki którym zachowanie ma swoją logikę. Według Northa instytucje to stworzone przez człowieka ograniczenia, które strukturyzują interakcje polityczne, ekonomiczne i społeczne. Składają się na nie ograniczenia nieformalne takie jak: sankcje, zwyczaje, tradycje, nieformalne kodeksy oraz reguły sformalizowane, czyli np. prawo. North podkreśla, iż w ciągu historii instytucje zostały wykreowane przez ludzi w celu stworzenia porządku oraz zredukowania niepewności w transakcjach [Skąpska 1999: 324]. W odniesieniu do rzeczywistości przejścia granicznego, za instytucję w sensie socjologicznym można uznać kontrolę graniczną wraz z jej elementami składowymi, takimi jak: kontrola paszportowa, kontrola celna $\mathrm{z}$ oględzinami pojazdu bądź rewizją szczegółową auta i osób nim podróżujących, a także kontrole: weterynaryjne, fitosanitarne oraz te odnoszące się do zdrowia publicznego i higieny. 
Zdaniem Knighta i Ensmingera [1998: 105-126] procesy instytucjonalizacji są swoistymi negocjacjami uwzględniającymi preferencje uczestniczących w nim aktorów społecznych. W realiach przejścia granicznego na przeciw siebie stają osoby, które inaczej definiują rzeczywistość społeczną. W opozycji do osób, które ze stałych przyjazdów do sąsiedniego kraju chcą czerpać dochód stają kontrolerzy ustanowieni przez państwo do dbania o interes ogólnospołeczny. Te dwie antagonistyczne role społeczne w wyniku interakcji redefiniują własne wizje rzeczywistości i przez proces instytucjonalizacji regulują swoje aktywności. W ten sposób ze spontanicznej, chaotycznej działalności utworzone zostają procedury aktywności. Przez stałe ich powielanie przeradzają się one w nawyk. Niestosowanie się do nich powoduje, że jednostki podlegają sankcjom. Na przejściu granicznym kara zostanie wymierzona zarówno osobie, która w sposób niebudzący wątpliwości przyzna się do przemytniczego charakteru swojej podróży, jak i kontrolerowi, który podczas podjętych czynności naruszy w jakikolwiek sposób godność turysty. Tym samym obie grupy aktorów społecznych stale stykających się w przestrzeni terminala samoograniczają się. Z powodu dużej liczby osób przekraczających granicę służby nie są w stanie w pełni skontrolować wszystkich podróżnych. Szczegółowej kontroli poddawani są turyści, którzy łamią już na wstępie normy wynegocjowane $\mathrm{w}$ procesie instytucjonalizacji. Tym samym kontrola graniczna jest w sensie socjologicznym rytuałem, który unaocznia istnienie instytucji. Wiedza o nim może okazać się skutecznym sposobem dla osób czerpiących zyski z nielegalnego przywozu towarów zza granicy. Jak stwierdzają Berger i Luckmann [1983: 118] podstawą przekazu znaczenia instytucji jest społeczne uznanie, że dana instytucja jest stałym rozwiązaniem określonego problemu danej zbiorowości. Dlatego potencjalni uczestnicy zinstytucjonalizowanych działań muszą być systematycznie zapoznawani z tymi znaczeniami. Ciekawym przypadkiem w analizie procesu instytucjonalizacji jest sytuacja, gdy jedna ze stron zrywa nieformalną społeczną umowę dotyczącą reguł panujących $\mathrm{w}$ interakcjach z przedstawicielami drugiej strony. Podczas przeprowadzonej przeze mnie obserwacji, takie zjawisko zaistniało przynajmniej kilkakrotnie i prawie zawsze było związane $\mathrm{z}$ wprowadzaniem nowelizacji w przepisach regulujących ruch graniczny. Zmiana norm powoduje, że utrwalona instytucja przekraczania granicy przestaje być wystarczającym źródłem dyspozycji odnoszących się do pożądanych zachowań i nie rozwiązuje problemu zbiorowości, jakim jest pokonanie rygoru kontroli. Dotychczasowe reguły zachowania zostają zakazane, próg tolerancji kontrolujących zostaje zdecydowanie obniżony. Jednak próżnia społeczna nie trwa długo. Praktycznie od razu podejmowane są próby wytworzenia nowego ładu. W niniejszym artykule chciałbym prze- 
analizować następujące po sobie etapy procesu instytucjonalizacji przekraczania granicy na przykładzie wprowadzenia ograniczenia na wywóz z Białorusi przez osoby fizyczne paliwa, które było efektem ogłoszonego w czerwcu 2011 roku rozporządzenia rządu w Mińsku. Dla celów analitycznych omawianego procesu wyróżniam dziewięć etapów: ogłoszenie zmiany, próba - ofiara, bunt, zanik aktywności, innowacja, reinterpretacja normy, testowanie, uspołecznienie, nowa praktyka.

\section{Ogłoszenie informacji o zmianie norm}

Informacja o zmianie przepisów jest traktowana w społeczności ludzi granicy jako zawieszenie dotychczasowych norm. Najczęściej badani informują się wzajemnie o planach wprowadzenia nowych przepisów ${ }^{3}$. Efekt niepewności potęguje poczucie zagrożenia, że dotychczasowa działalność może w przyszłości okazać się niemożliwa ${ }^{4}$. Respondenci swoją sytuację określają jako koniec pewnego etapu w życiu. Są nawet skłonni do pewnych podsumowań ${ }^{5}$ Jednoznacznie narzekają i wyrażają swój sprzeciw wobec działań podejmowanych przez prawodawców. Próbują unaocznić, że nowe przepisy godzą w ich życie ${ }^{6}$. Niektórzy nie dowierzają, że zmiany naprawdę zaistnieją ${ }^{7}$. Poziom aktywności ludzi na granicy rośnie. Każdy stara się wykorzystać do maksimum obecnie istniejącą sytuację. Kiedy informacja zostanie potwierdzona czy to przez środki masowego przekazu, czy też funkcjonariuszy pracujących na granicy, rozpoczyna się proces deinstytucjonalizacji dotychczasowego porządku społecznego. Dotychczasowa umowa społeczna pomiędzy aktorami przejścia granicznego zostaje wypowiedziana. Część jednostek podejmuje irracjonalne działania, osoby zajmujące się przygranicznym han-

3 W przypisach podaję wypowiedzi, które były świadectwem zaobserwowanych postaw. Najczęściej wyrażane one były w żargonie, który dominuje w komunikacji na przejściu granicznym. W pracy umieszczam polskie tłumaczenia, starając się oddać w pełni oryginalną treść.

4 Wypowiedź 40-letniej mieszkanki Grodna: „W kolejce mówili, że to już koniec wyjazdów do Polski. Skończy się handel. Łukaszenka nas nie lubi, według jego ludzi nie jesteśmy patriotami, bo my na Zachód jeździmy, więc wymyślili już jak nam pracę zabrać."

557 - letni robotnik z Grodna: „Na granicy chleb nie był łatwy, ale był. Niektórzy nawet rezygnowali z pracy, żeby mieć więcej czasu na przyjazdy. Całe szczęście, że ja mam jeszcze pracę w fabryce. Żyć będzie dużo ciężej, ale jak zakazali to już jest koniec.”

630 - letni nauczyciel z Grodna: „Przecież mówią, że na Białorusi jest wolność i demokracja. To jak można zakazać ludziom podróżowania. Przecież tak nie może być. Przecież nikogo nie okradam. To rząd okrada moją rodzinę. Odsprzedam białoruskie paliwo, w zamian kupię na użytek rodziny polskich tańszych produktów. Mało zarabiam, więc chcę jak najlepiej wykorzystać to co mam. Dlaczego tego mi się zabrania.

7 38-letni mieszkaniec Wołkowyska: „Nie zakażą tych wyjazdów. Tego nie da się zrobić. Ludzie i tak będą jeździć. W kolejce mają za dużo czasu to plotkują." 
dlem są bardziej skłonne do podjęcia przemytniczych prób, nawet jeśli nie są w stanie w dobry sposób ukryć nielegalnie przewożonych towarów. ${ }^{8}$ Podczas obserwacji na etapie ogłoszenia informacji o zmianie norm zarejestrowałem zjawisko chęci rezygnacji z dalszej działalności granicznej. Obserwowalne były fakty pożegnania z przestrzenią przejścia granicznego 9 .

Nowe przepisy wprowadzono o północy 12 czerwca 2011 roku. W kilka chwil po godzinie 23 czasu polskiego, kiedy odprawiono ostatnich kierowców, którym udało się wyjechać z Białorusi przed nowelizacją normy prawnej przejście opustoszało. Przez $5 \mathrm{dni}^{10}$ ruch samochodów osobowych praktycznie zamarł. Ludzie granicy swoją aktywność przenieśli z przestrzeni przejścia granicznego na jego najbliższe otoczenie.

\section{Nieudane próby - pierwsze ofiary}

Tuż po wprowadzeniu nowych przepisów, kierowcy próbujący przekroczyć granicę, niestosujący się do zaostrzonej normy, byli zawracani na teren Białorusi, w przypadku obywateli Rzeczpospolitej nie byli wpuszczani na terytorium polskiego wschodniego sąsiada. Funkcjonariuszy służb granicznych wspierały dodatkowe patrole białoruskiej milicji. Ostrzegano turystów, że niepodporządkowanie się nowym regułom spowoduje sankcje. Kiedy nowe przepisy zaczęły w rzeczywistości obowiązywać, pojawili się pierwsi śmiałkowie, którzy próbowali sforsować granicę. Wysokość naliczanego im cła wywozowego powodowała, że przekraczanie granicy przestało być opłacalne ${ }^{11}$. Także ukrycie paliwa w aucie osobowym nie jest łatwe. Służby kontrolne zyskały zdecydowaną przewagę nad przedstawicielami zbiorowości zajmującymi się handlem transgranicznym. Po nieudanych próbach podjęcia działań, które rozwiązałyby dla społeczności problemową sytuację rozpoczął się etap jawnego konfliktu.

8 Wypowiedź 40-letniego mężczyzny ukaranego za wykroczenie skarbowe: „Nigdy mnie na przemycie nie złapali, bo i nic nie chowałem. Teraz jak się dowiedziałem, że to koniec z wyjazdami do Polski to postanowiłem zaryzykować. Raz się udało, to i drugi raz chciałem. Jeszcze więcej papierosów załadowałem, ale pecha miałem to wpadłem".

60 - letni emeryt z Grodna: „Pięć lat dzień w dzień byłem na granicy. Dzisiaj chyba ostatni raz jestem. Mówią, że od niedzieli już z paliwem nie wypuszczą. Tyle razy pana widziałem, ale czas już się pożegnać. Może i wy się cieszycie, że nas nie będzie, ale jak nas nie będzie to i wam pracy zabraknie. Z zamknięcia granicy nic dobrego wyjść nie może".

10 Początkowo ograniczenie dotyczyło 1 wyjazdu w ciągu 5 dni, w kolejnych miesiącach zostało zaostrzone do 1 wyjazdu w okresie 8 dni.

11 Wypowiedź 30-letniej mieszkanki podgrodzieńskiej wsi: „Powiedziałam, że zapłacę cło za paliwo, bo muszę pojechać do Polski. Dokładnie jeszcze nie podliczyłam, ale był to duży błąd. Teraz to paliwo zamiast 3 zł za litr kosztowało pewnie ze 3 dolary. Żaden z tego biznes". 


\section{Bunt - protesty przed przejściami granicznymi}

Stali bywalcy przejść granicznych praktycznie od początku zapowiadali podjęcie działań protestacyjnych na przejściu granicznym, kiedy miałoby okazać się, że ich dotychczasowa działalność zostanie poważnie ograniczona. Już 12 czerwca około godz. 18 rozpoczęła się blokada przejścia granicznego. Około 300 osób zebrało się na drodze łączącej oba kraje. W proteście turyści zakupowi wykorzystywali również dzieci. Demonstranci blokowali drogę zarówno swoimi pojazdami, jak i wkroczyli na przejścia dla pieszych. O akcji protestacyjnej informowały zarówno polskie, jak i białoruskie środki masowego przekazu. W celu przywrócenia drożności drogi dojazdowej do granicy, białoruskie władze były zmuszone użyć oddziałów specjalnych milicji. W wyniku przepychanek z funkcjonariuszami kilku demonstrantów doznało obrażeń. Piętnaście osób zostało zatrzymanych. Kilkanaście następnych w kolejnych dniach po proteście zostało ukaranych grzywnami. Demonstranci chętnie filmowali całe zajście. Materiały z protestu umieścili w Internecie ${ }^{12}$. Podobne manifestacje przeprowadzono także na innych przejściach. W Brześciu w buncie uczestniczyło ponad 100 osób. Forma otwartego protestu nie przyniosła żadnych zmian. Władze nie zamierzały zliberalizować nowego prawa. Jednakże pojawiły się pierwsze symptomy, które wskazały, w jaki sposób można obejść zaostrzoną normę. Podczas protestu na przejściu w Brześciu funkcjonariusze, którzy początkowo zabronili wyjazdu kierowcy zgodzili się, aby pojazd z pełnym zbiornikiem paliwa opuścił terytorium Białorusi pod warunkiem, że będzie prowadzony przez inną osobę. Informacja o tej praktyce szybko dotarła na pozostałe przejścia.

\section{Krótkotrwały zanik aktywności}

Po wzmożonej aktywności ludzi granicy w pierwszej połowie czerwca 2011 roku, w drugiej części miesiąca nastąpił wyraźny spadek natężenia ruchu. Po protestach z 12 czerwca kilkakrotnie próbowano zorganizować kolejne akcje, ale miały one zdecydowanie mniejszy zakres. Zbiorowość ludzi granicy w omawianym okresie była wyjątkowo rozbita. Najmniej konformistycznie nastawione jednostki miały problemy $\mathrm{z}$ organami ścigania za udział w proteście. Osoby bardziej uległe wiedziały, że na granicy trwał okres wzmożonych kontroli, który nie był najlepszym czasem dla transgranicznego handlu. Respondenci wspominają także, że w opisywanym czasie podjęto szereg działań

12 Zob. m.in.: Bruzgi: Razgon demonstracji Amanom,w: http://www.youtube.com/watch?v=2UWjbsmy Z00\&feature=related [15.11.2012]. 
władz, które miały zniechęcić do podejmowania turystyki zakupowej ${ }^{13}$. Oficjalnie zakazano wyjazdów do Polski przedstawicielom wielu zawodów, np. funkcjonariuszom służb. Kilku z badanych przyznało, że woleli przeczekać $\mathrm{w}$ domu ten trudny okres na granicy. Jednak z zaciekawieniem oczekiwali wiadomości o rozwoju sytuacji ${ }^{14}$.

Natężenie w ruchu osobowym na przejściu granicznym, w pierwszym okresie po wprowadzeniu zmian, spadło o około 35 procent Jednakże, już po kilku dniach od nowelizacji przepisów było jasne, że ruch na granicy na stałe nie zamarł. Dosyć szybko pojawili się nowi aktorzy. Dla wielu osób ukształtowała się nowa możliwość korzystania z przejścia granicznego. Zmniejszenie kolejek spowodowało, że przez granicę zaczęli przejeżdżać okazjonalni turyści zakupowi, których dotąd długość oczekiwania na odprawę odstraszała od przyjazdu do kraju ościennego ${ }^{15}$.

Dosyć szybko bierność ludzi granicy została przerwana. Ruch na terminalu zmienił swoją charakterystykę. Przed wprowadzeniem przepisów ograniczających wywóz paliwa, w większości pojazdów podróżował jedynie kierowca. Po nowelizacji w samochodach pojawiło się więcej pasażerów. Obecnie liczba osób odprawiających się przez granicę jest większa niż przed wprowadzeniem nowego przepisu, ale liczba aut osobowych utrzymuje się na zdecydowanie niższym poziomie (tabela 1). Spadek liczby odprawianych pojazdów wynosi około 30 procent.

$\overline{13}$ 24-letni mieszkaniec Grodna: „Dyrektor przedsiębiorstwa nakazał wszystkim zwrócenie Karty Polaka. Mnie dodatkowo wezwał do siebie i musiałem tłumaczyć się, dlaczego jeżdżę do Polski. Przez jakiś czas rzeczywiście przestałem jeździć, bo bałem się, że wyrzucą mnie z pracy, a i na granicy ciężko było cokolwiek zarobić".

1430 - letnia mieszkanka Szczuczyna: „Nie jeździłam wtedy. Za daleko miałam, żeby mnie zawrócili. Wolałam z dziećmi w domu pobyć. Jak już się ustabilizowało to i jeździć zaczęłam. Wcześniej jeździłam 2-3 razy w tygodniu, a potem 6 razy w miesiącu".

15 28-letni kierowca z Grodna: „Miałem Kartę Polaka, ale jakoś nie jeździłem do Polski. Za długie kolejki. W pracy nie było tego jak zgrać. A teraz jak się bardziej pusto zrobiło to parę razy skoczyłem na zakupy. Może to i dobrze, że im ograniczyli. Wystarczy mi w zupełności jak raz na tydzień pojadę do Polski”. 
Tabela 1. Wielkość ruchu (w obu kierunkach) na drogowym przejściu w Kuźnicy

\begin{tabular}{|c|c|c|c|}
\hline Rok & Miesiąc & Liczba osób & $\begin{array}{c}\text { Liczba samochodów } \\
\text { osobowych }\end{array}$ \\
\hline \multirow{4}{*}{2009} & maj & 186251 & 91058 \\
\hline & czerwiec & 173739 & 85374 \\
\hline & lipiec & 194442 & 95546 \\
\hline & sierpień & 209149 & 102679 \\
\hline \multirow{4}{*}{2010} & maj & 190771 & 98658 \\
\hline & czerwiec & 185287 & 94441 \\
\hline & lipiec & 174424 & 88552 \\
\hline & sierpień & 201380 & 100702 \\
\hline \multirow{4}{*}{2011} & maj & 200403 & 101153 \\
\hline & czerwiec & 165308 & 74281 \\
\hline & lipiec & 158370 & 64450 \\
\hline & sierpień & 193397 & 78448 \\
\hline \multirow{4}{*}{2012} & maj & 195424 & 71968 \\
\hline & czerwiec & 193087 & 70216 \\
\hline & lipiec & 200458 & 72090 \\
\hline & sierpień & 212014 & 72665 \\
\hline
\end{tabular}

Źródło: obliczenia własne na podstawie danych Podlaskiego Oddziału Straży Granicznej.

\section{Innowacja}

Niedługo po wprowadzeniu zmiany przepisów, która zburzyła dotychczasowy ład instytucjonalny, pojawiły się pierwsze próby innowacyjnego sposobu rozwiązania problemu społecznego, przed jakim stanęła zbiorowość ludzi granicy. Działania, takie jak: oczekiwanie, iż nowe prawo nie będzie egzekwowane, czy też, że władze w Mińsku na skutek nieposłuszeństwa społecznego wycofają się z nowelizacji normy prawnej, okazały się nieskuteczne. Jednakże już po kilku dniach, po stłumionych procesach, pojawiły się aktywności ludzkie, które pozwalały przekroczyć granicę. Najprostszym i najdostępniejszym sposobem okazało się przejeżdżanie granicy samochodem z prawie pustym bakiem paliwa. Wielu z podróżujących twierdziło, że jedzie przez granicę częściej niż jeden raz w ciągu pięciu dni, ponieważ zadeklarowało w białoruskim urzędzie celnym, że w zbiorniku posiada zaledwie kilka litrów paliwa i od tej niewielkiej 
ilości opłaciło należności celne ${ }^{16}$. Praktyka ta ograniczała rentowność przedsięwzięcia, ale pozwalała skupić się na innych aktywnościach.

Drugim innowacyjnym sposobem było wprowadzenie do zbiorowości ludzi granicy nowych członków. Dotychczas przeważnie handlem przygranicznym zajmowała się jedna osoba w rodzinie. Kiedy ona wykorzystała już swoją normę paliwową, do granicznej gry musiał zostać wprowadzony kolejny członek rodziny. Częstą praktyką była zmiana kierowców w celu spełnienia wymogów kontroli. Na przejściu granicznym pojawiali się kierowcy, których umiejętności prowadzenia pojazdu sugerowały, że rzadko pełnią tę rolę, a osoba poprzednio prowadząca auto stawała się pasażerem. Po przekroczeniu granicy następowała zamiana i powrót do wcześniej pełnionych ról.

Trzecią z zaobserwowanych praktyk o charakterze innowacyjnym było przekraczanie granicy pojazdem napędzanym gazem lpg. Pomimo, że takie pojazdy do rozruchu potrzebują niewielkiej ilości etyliny, graniczni mechanicy dosyć szybko przygotowali swoje pojazdy w taki sposób, żeby benzyna nie przeszkadzała w przekraczaniu granicy.

Czwartym rodzajem zarejestrowanych innowacyjnych działań było wprowadzenie do środowiska ludzi granicznych osób obsługujących tzw. „shop tour". Właściciel busa szybko przerabiał go na autobus rejsowy. Dzięki temu mógł on bez ograniczeń przekraczać granicę. Co ciekawe, często zdarzało się, że stale podróżowały nim te same osoby ${ }^{17}$.

Wszystkie innowacyjne zachowania podejmowane przez ludzi granicy były, w sensie socjologicznym, propozycją utworzenia nowego porządku społecznego w przestrzeni przejścia granicznego zburzonego w wyniku wprowadzenia nowej normy prawnej. Ustawodawca w zamierzeniu chciał ograniczyć ruch przez granicę. Była to próba przymknięcia przejścia, dlatego też nie dopuszczał, aby w łatwy sposób zbiorowość graniczna zinstytucjonalizowała nowe reguły gry. Po próbach innowacyjnych działań ze strony transgranicznych podróżnych władze białoruskie zaostrzyły przepisy.

$\overline{16}$ Fragment rozmowy z 41-letnim mieszkańcem Mińska: „Buduję dom. W Polsce kupuję materiały budowlane, są dużo tańsze niż u nas. W zasadzie wszystko co mi teraz potrzebne już zawiozłem do Kuźnicy. Teraz tylko muszę przerzucić to na Białoruś. Jest $\mathrm{z}$ tym dużo zawracania głowy. Po troszeczku przewożę. Nie czekam na te 5 dni. Wolę zapłacić kilka dolarów cła, ale szybciej przewiozę materiały i na nich więcej oszczędzę. Po prostu jest to jeszcze jeden dodatkowy koszt. Moi znajomi też są niezadowoleni, że im już paliwa nie przywożę tak często”.

17 Cytat z rozmowy z kierowcą obsługującym „shop tour”: „Jest nas dwóch kierowców. Jeździmy różnie, raz lub dwa razy dziennie. Mamy 18 stałych klientów. Zabieramy i odwozimy ich spod domu. Cena biletu od 12 do 20 dolarów. Trasa praktycznie stała: Auchan, Biała, Alfa, rynek na Kawaleryjskiej i na koniec Tesco w Sokółce. Czasami na życzenie coś tam zmieniamy. Nie zawsze wszyscy klienci jeżdżą, czasami kogoś innego weźmiemy. Jak wielu nie chce jechać to po prostu rezygnujemy z kursu". 


\section{Reinterpretacja przepisów - dookreślenie norm}

Odpowiedzią ustawodawcy na aktywność ludzi granicy była zmiana interpretacji przepisów. Kiedy zamiana kierowców i możliwość ponownego wykorzystania normy na wywóz paliwa zaczynała stawać się skuteczną praktyką, została zakazana. Jak się okazało, funkcjonariusze odtąd mieli normę paliwową przypisywać nie do konkretnej osoby, ale do środka przewozowego. W odpowiedzi na takie działanie członkowie zbiorowości stale wykorzystujący przestrzeń terminali, zaczęli przekraczać granicę innym pojazdem niż za pierwszym razem. Władze białoruskie, aby ukrócić i ten proceder wydłużyły okres z 5 do 8 dni, w jakim dopuszczalny był wywóz paliwa. Takie działanie przyczyniło się do tego, iż koszty uzyskania międzynarodowego ubezpieczenia dla posiadaczy samochodów osobowych stały się bardzo wysokie. Najkrótszy okres wystawienia tzw. Zielonej Karty to 15 dni. Białoruscy ubezpieczyciele oferują ją na: 15 dni, miesiąc, 3 miesiące, 6 miesięcy i rok $^{18}$. Przed wprowadzeniem ograniczenia na wywóz paliwa turysta, który korzystał z piętnastodniowego ubezpieczenia, którego koszt uprzednio i obecnie wynosi 30 euro, przekraczał granicę przeważnie od 10 do 12 razy. Po pierwszej zmianie przepisów, z taką samą polisą, mógł już jedynie trzykrotnie wyjeżdżać do kraju sąsiada. Po zaostrzeniu przepisów piętnastodniowa Zielona Karta wystarczała zaledwie na dwa wyjazdy. Kiedy turyści zakupowi chcieli wprowadzić do granicznej gry kolejny pojazd, zawsze wiązało się to $\mathrm{z}$ wykupieniem kolejnej polisy. Pomimo, że cena Zielonej Karty nie wzrosła, to jej koszt dla członków zbiorowości granicznej zdecydowanie wzrósł. Faktyczna cena ubezpieczenia dla posiadacza jednego auta wzrosła de facto z 2 euro za przejazd, przy założeniu, że przekraczał on granicę codziennie, do 15 euro. Jednak i takie działania władz nie zniechęciły wszystkich osób. Ostatecznie białoruska służba celny nakazała, aby norma paliwowa była przypisywana zarówno do środka przewozowego, jak i osoby. Tym samym zakończył się proces dookreślenia warunków granicznej gry.

\section{Testowanie rentowności}

W nowych warunkach członkowie zbiorowości ludzi granicy podejmowali działania, które miały na celu wypracowanie skutecznych praktyk rozwiązujących problemy codzienności granicznej. Zauważalny był wzrost korzystania z usług publicznych środków transportu, zarówno w ruchu kolejowym, jak i drogowym. Niektórzy członkowie społeczności ludzi granicy ponosili dodatkowe koszty związane z opłatami wywozowymi, czy też z wydatkami na do-

18 Dane pochodzą ze strony internetowej firmy Biełgosstrach: http://bgs.by/insurance/17/940/5616/ [15.11.2012]. 
datkowe ubezpieczenia pojazdów lub wyrobieniem wiz dla osób dotąd z nich niekorzystających. Podczas obserwacji widoczny był zdecydowany wzrost liczby osób zgłaszających się do odprawy celnej na kierunku wywozowym z Polski po to, żeby uzyskać zwrot podatku VAT przysługujący podróżnym spoza Unii Europejskiej. Sądzę, że wprowadzenie zmian w przepisach w znaczący sposób wpłynęło na przestrzeń przejścia granicznego. Dotychczasowe praktyki musiały zostać zastąpione nowymi, które dopiero krystalizowały się. Uważam, że rentowność danego zjawiska była głównym czynnikiem decydującym o tym, czy dane działanie przekształcało się w rutynowe zachowanie. Ograniczone możliwości zarobku na nielegalnej sprzedaży paliwa spowodowały, że wysiłki ludzi granicy skoncentrowały się w większym stopniu na wwozie towarów zakupionych w Polsce ${ }^{19}$. Osoby, które głównie przez wpadki podczas kontroli po białoruskiej stronie, nie mogły pozwolić sobie na ryzyko przewożenia większej ilości towarów poszukiwały nowych szlaków. Część osób wjeżdżających do Polski przez przejście w Kuźnicy wracało na Białoruś przez terytorium Litwy. Po przetestowaniu opłacalności podejmowanych działań, te najbardziej dochodowe zostały zrutynizowane. Tym samym kształtował się nowy porządek. Jednakże zanim stał się on faktem społecznym, musiał zostać przyswojony przez większą liczbę jednostek. Na tym etapie był on dostępny jedynie członkom zbiorowości, których charakteryzowała otwartość na podejmowanie innowacyjnych, nonkonformistycznych aktywności.

\section{Uspołecznienie najskuteczniejszych praktyk}

Kolejnym etapem, zaobserwowanym podczas analizy procesów instytucjonalizacji na przejściu granicznym, jest rozprzestrzenianie się subiektywnych działań jednostek w obrębie zbiorowości ludzi granicy. Najefektywniejsze praktyki stają się rutynowymi działaniami. Funkcjonariusze nie zostają wyposażeni przez prawodawcę w kolejne narzędzia, które miałyby ograniczać innowacyjną aktywność turystów zakupowych. Brak prób nowej, jeszcze bardziej zaostrzonej reinterpretacji wprowadzonych przepisów powoduje, iż zachowania podsuwane przez ludzi granicy stają się akceptowane przez kontrolujących.

Nierozwiązany konflikt społeczny na przejściu granicznym nie służy żadnej ze stron. Funkcjonariusze dysponują aktami prawnymi ustanowionymi przez legislatora danego kraju. Normy mają zapewnić dobro społeczne. Jednakże $\mathrm{w}$ wielu wypadkach jest to niemożliwe, a prawo jest wręcz ułomne. W opozy-

19 35-letni mieszkaniec Grodna: „Kiedyś tymi Vat-ami nie zawracałem sobie głowy. Pojechałem, zostawiłem całą normę, zrobiłem zakupy i wracałem. Mniej było tego planowania. Teraz liczy się każda złotówka. Człowiek musi lepiej kombinować. Nie stać mnie na puste przejazdy. Jest też większe ryzyko, bo jak wpadniesz, to nie ma już kiedy odrobić i ponosisz straty. 
cji do kontrolerów stają jednostki, które swoje działania legitymizują prawem do życia lub nieskrępowanej aktywności. Osoby trudniące się przemytem często mają poczucie, iż prawodawca nie tylko o nich nie zabiega, a jest wręcz ich wrogiem. Rzeczywistość przejścia granicznego pokazuje, że pozornie antagonistyczne zbiorowości, z jednej strony reprezentujące państwo unaocznione w postaci funkcjonariuszy, a $z$ drugiej uosabiające jednostki, często wykluczone, bądź spychane z życia ogólnospołecznego, dbające jedynie o osobiście skonstruowane prawo do życia, mogą wytworzyć instytucjonalną przestrzeń, gdzie skanalizowany zostanie ten konflikt. Jego rozwiązanie przynoszą praktyki, dzięki którym turyści zakupowi mogą ze swojej aktywności czerpać dochód i jednocześnie w jawny sposób nie łamią one zasad, do strzeżenia których zostali powołani strażnicy prawa. Takie działania szybko zostają zrutynizowane i stają się obiektywnymi faktami dla osób chcących podjąć działalność na granicy. Wiedza o nich jest specyficznym kapitałem. Jednakże omawiane zachowanie ma charakter społeczny i może być naśladowane przez inne jednostki.

Analizując literalnie prawo przygotowane przez ustawodawców Polski i Białorusi działalność członków zbiorowości ludzi granicy powinna okazać się zupełnie nieopłacalna. Jednak sytuacja ekonomiczna wielu osób zamieszkujących tereny przygraniczne zmusza ich do podejmowania nielegalnej aktywności. Ich zachowanie jest zgodne z logiką, że prawo, które nie jest egzekwowane ich nie obowiązuje. Tym samym zagospodarowują oni przestrzeń społeczną, którą ustawodawcy przygotowali dla zwykłych turystów. Pomimo, że intencje podejmowanej działalności przez ludzi zbiorowości granicy są zgoła odmienne, to skutecznie wcielają się w role, jakie założyli rządzący. Próby eliminowania takich jednostek z przestrzeni granicznej przez wprowadzenie nowych rygorów powodują, że ci, dla których była ona pierwotnie utworzona w jeszcze większym stopniu są zniechęcani, aby z niej korzystać.

Innowacyjne jednostki nie działają w próżni społecznej. Często, aby zrealizować zamierzone praktyki muszą swoją wiedzą dzielić się z innymi użytkownikami terminali granicznych. Ciągłe interakcje członków analizowanej zbiorowości powodują, że wiedza o najskuteczniejszych sposobach funkcjonowania w rzeczywistości przejścia granicznego przestaje być informacją tajną. Naśladownictwo skutecznych praktyk może okazać się wystarczającym sposobem do realizacji postawionych przez jednostkę celów.

\section{Nowe praktyki powstałe w wyniku zmiany normy prawnej}

Efektem uspołecznienia najskuteczniejszych praktyk jest utrwalenie nowego porządku. Zmiana normy prawnej, która zburzyła dotychczasowe instytucje rozpoczęła ponowny proces instytucjonalizacji, którego celem jest ukształ- 
towanie się nowych praktyk. Przeobrażone działania muszą być aprobowane zarówno przez kontrolowanych, jak i kontrolujących. Dzięki temu dynamicznemu procesowi w przestrzeni społecznej przejścia granicznego wytworzyły się, czy też uległy przeobrażeniu dotychczas dominujące zjawiska społeczne. Podczas prowadzonej obserwacji stwierdziłem sześć nowych typów praktyk, które powstały z powodu ograniczeń wprowadzonych przez władze w Mińsku w czerwcu 2011 roku.

Najbardziej zauważalnym wynikiem zmiany normy prawnej jest wyeliminowanie z przestrzeni terminali osób, które codziennie przekraczają granicę państwową. Z badań przeprowadzonych przez Główny Urząd Statystyczny [Badnie... 2010-2012] wynika, iż przed nowelizacją przepisów około 7-9 procent cudzoziemców ${ }^{20}$ deklarowało, że granicę przekracza codziennie. Dominująca grupa osób w okresie przed wprowadzeniem restrykcji (od 52 - do 54 procent) do Rzeczpospolitej przyjeżdżała kilka razy w tygodniu. Obecnie ponad 90 procent respondentów deklaruje, że na terminalu granicznym odprawia się jedynie kilka razy w miesiącu. W okresie dookreślania porządku instytucjonalnego następował stały spadek częstotliwości przekraczania granicy (tabela 2).

Tabela 2. Częstotliwość przekraczania granicy polsko - białoruskiej na przejściach w województwie podlaskim przez cudzoziemców w okresie III kwartał 2010 - III kwartał 2012

\begin{tabular}{|c|c|c|c|c|}
\hline Okres & Codziennie & $\begin{array}{l}\text { Kilka razy } \\
\text { w tygodniu }\end{array}$ & $\begin{array}{l}\text { Kilka razy } \\
\text { w miesiącu }\end{array}$ & $\begin{array}{c}\text { Rzadziej niż kilka } \\
\text { razy w miesiącu }\end{array}$ \\
\hline III kwartał 2012 & 0,3 & 0,9 & 91,5 & 7,3 \\
\hline II kwartał 2012 & 0,0 & 1,2 & 93,8 & 5,0 \\
\hline I kwartał 2012 & 0,2 & 0,4 & 92,7 & 6,7 \\
\hline IV kwartał 2011 & 0,1 & 3,3 & 88,4 & 8,2 \\
\hline III kwartał 2011 & 0,9 & 11,9 & 81,5 & 5,7 \\
\hline II kwartał 2011 & 5,3 & 53,3 & 34,7 & 6,7 \\
\hline I kwartał 2011 & 8,6 & 54,3 & 32,9 & 4,2 \\
\hline IV kwartał 2010 & 7,2 & 52,1 & 35,3 & 5,4 \\
\hline III kwartał 2010 & 7,7 & 53,5 & 33,0 & 5,8 \\
\hline
\end{tabular}

Źródło: obliczenia własne na podstawie badań Głównego Urzędu Statystycznego.

$\overline{20}$ Za reprezentatywną dla populacji zbiorowości ludzi granicy uważam grupę cudzoziemców, ponieważ w okresie przeprowadzonych przeze mnie badań obywatele Polski stanowili zdecydowaną mniejszość. Odsetek osób legitymujących się paszportem Rzeczpospolitej w stosunku do ogółu przekraczających granicę nie był wyższy niż 10 procent. 
Z obserwacji własnych, a także $\mathrm{z}$ danych statystycznych wynika, że ogólna liczba osób przekraczających granicę, w obu kierunkach, przed i po zmianie normy prawnej, oscyluje na poziomie 200 tysięcy osób. Skoro liczba odpraw podróżnych nie zmniejszyła się, ale zdecydowanie zredukowana została częstotliwość przekraczania granicy należy stwierdzić, iż znacząco powiększyła się populacja zbiorowości ludzi granicy. Pojawienie się debiutantów, którzy nie zawsze byli zaznajomieni z realiami rzeczywistości przejścia granicznego powodowało wiele stresujących sytuacji zarówno dla kontrolowanych, jak i kontrolujących. Nieznajomość wzorów zachowania, kodu, rytuałów, norm przejścia było odbierane jako niecodzienne zjawisko. W moim przekonaniu obecnie owo zjawisko osłabia się. Debiutanci, którzy wkroczyli na teren graniczny po zmianie przepisów prawa, po rocznym koegzystowaniu wśród ludzi granicy, w większości przypadków zasymilowali się z dominująca zbiorowością.

Niezamierzonym efektem wprowadzenia nowego porządku instytucjonalnego jest specyficzny wytwór materialny społeczności działających zgodnie z logiką kultury granicy. Na przejściu granicznym pojawiło się wiele samochodów, które granicę przekraczają bez paliwa. Większość z nich ma odłączone pompy paliwowe lub zupełnie zdemontowane zbiorniki. Napędzane są gazem lpg. Po stronie białoruskiej zgłaszają się do kontroli tzw. czerwonym pasem. Owe samochody są poddawane oględzinom dokonywanym specjalnym skanerem, który stwierdza, czy w pojeździe przewożone jest paliwo. W przypadku nie stwierdzenia nieprawidłowości kierowca otrzymuje zezwolenie na opuszczenie terytorium Białorusi częściej niż jeden raz w ciągu ośmiu dni bez konieczności dokonywania opłat celno - podatkowych.

Nową praktyką, szczególnie zauważalną w nocy z piątku na sobotę jest podróżowanie dużej liczby osób rejsowymi autobusami. Zdecydowana większość z nich jest określana w gwarze granicznej jako „shop tour”. Ten specyficzny rodzaj zorganizowanej turystyki zakupowej jest również efektem wprowadzenia ograniczeń na wywóz paliwa ${ }^{21}$.

Zauważalny jest też wzrost liczby osób podróżujących w jednym środku przewozowym. Przed zmianą przepisów średnio w samochodzie podróżowały dwie osoby. Obecnie statycznie w jednym aucie granicę przekraczają prawie trzy osoby ${ }^{22}$.

\footnotetext{
21 Fragment rozmowy z uczestniczką „shop tour”: „Pracuję od poniedziałku do piątku. Kiedyś nie miałam jak jeździć do Polski, bo za bardzo nie miałam z kim. Polskie towary kupowałam na grodzieńskim bazarze, ale one ciągle drożały. W końcu wyrobiłam wizę i teraz w sobotę rano jeżdżę na taką wycieczkę po białostockich galeriach. Zakupy u was są zdecydowanie tańsze. Koszt wycieczki to około 20 euro i za wizę musiałam kolejnych 60 zapłacić". Dane na podstawie danych POSG i obserwacji własnych.
} 
Zmiana przepisów wpłynęła także na inne postrzeganie czasu na granicy. Dotychczas graniczna gra nie musiała uwzględniać zmiany daty, obecnie jest to jej ważny element. $Z$ informacji respondentów wynika, że już od godziny 20 czasu polskiego przed przejściem po białoruskiej stronie tworzą się dwie kolejki. W jednej ustawiają się osoby, które chcą jeszcze tego samego dnia udać się do kraju sąsiada, w drugiej zaś podróżni będą mogli to uczynić dopiero po północy. Jednakże liczba osób, które są w podobnej sytuacji determinuje ich do wcześniejszego zajęcia dogodnego miejsca w strefie nadgranicznej ${ }^{23}$.

\section{Zakończenie}

Pomimo, że zmiana normy prawnej zburzyła dotychczasowy porządek społeczny, to jednak nie spowodowała, rozwiązania problemów, na które miała być odpowiedzią. Nawet doraźny sukces w jednej kwestii, często powoduje ukształtowanie się kolejnych, dotąd niezauważalnych, niekorzystnych zjawisk. Społeczna rzeczywistość jest na tyle dynamiczna, iż prawie zawsze żywiołowe działania ludzkie są efektywniejsze niż abstrakcyjne, trudno egzekwowalne prawa. W moim przekonaniu większość zmian norm prawnych może być zinstytucjonalizowana przez innowacyjnie działające jednostki. Należy podkreślić, że kultura granicy określająca wzory zachowania większości jednostek w obrębie przejścia granicznego jest zasadniczo różna od kultury osób, które tworzą pra-

23 Jako potwierdzenie tej tezy przytaczam materiał zebrany podczas badania. Cytat pochodzi z rozmowy $\mathrm{z}$ osobą zajmująca się handlem na grodzieńskim bazarze i zaopatrującą się w artykuły na białostockim rynku: „Kiedy jadę po towar na «rynek kawaleryjski» w Białymstoku wyjeżdżam z domu ok. 20 (godziny są podane według czasu białoruskiego - w nawiasach przyp. autora). Przed granicą (ok. 20 km od miejsca zamieszkania) przez 4 godziny stoję w drugiej kolejce, tej, która zacznie podjeżdżać, gdy zmieni się data. Jak się dobrze ustawię to w 30 minut uda mi się przeprawić. Wtedy mam dużo czasu. Często kładę się jeszcze na trochę spać. Po 3, 4 godzinach jadę dopiero do Białegostoku lub też załatwiam inne sprawy, na które wcześniej nie było czasu (głównie zakupy, organizacja osób, które pomogą przewieźć towar przez granicę). A jak jest duża kolejka to ten czas w niej przestoję. W kolejce przysypiam, film oglądam lub rozmawiam ze znajomymi. Najpóźniej o 6 jestem w Białymstoku. Spóźniam się tylko wtedy, jak skierują mnie na «jamę» i tam dodatkowych kilka godzin tracę (w kolejce osób oczekujących na rewizję szczegółową). Czasami jest tak późno, że już nie ma sensu jechać na rynek. Na pusto też wracać jest bez sensu, więc zostaję jeden dzień dłużej. Z powrotem staram się być na granicy jak najwcześniej. Później jak 14 - 15 to już oznacza dużą kolejkę. Generalnie na te $90 \mathrm{~km}$ (w obie strony $180 \mathrm{~km}$ ) trzeba poświęcić cały dzień. Nigdy nie wiesz jak będzie. Teraz nawet jak nie ma kolejek to nie ma jak szybko przejechać, bo ten zakaz raz na 8 dni powoduje, że i tak czekasz na zmianę daty, a że sam nie czekasz to jak możesz jechać to jest już kolejka. Pan to rozumie (respondent rozmawiał z funkcjonariuszem Służby Celnej - dop. M.D.), ale tak innym wyjaśnić to jest ciężko”. 
wo. Brak zrozumienia jej fenomenów powoduje, że normy stanowione przez ustawodawców często są omijane.

Ponadto pojęcie kary jest inaczej rozumiane przez członków zbiorowości ludzi granicy. Nałożenie na podróżnego obowiązku opłacenia mandatu karnego czy grzywny w wielu przypadkach zamiast odstraszyć od nielegalnych zachowań jeszcze bardziej jednostkę zespala z przemytniczym środowiskiem. Przez turystów zakupowych mandat jest często traktowany jako dodatkowy koszt podróży. Sądzę, że kary o charakterze niefinansowym są zdecydowanie bardziej dotkliwe dla członków zbiorowości granicy. Jedynie odmowa wjazdu na terytorium Polski, odebranie czy też zakaz ubiegania się o wizę spowoduje, że cudzoziemiec zostanie wyeliminowany z przestrzeni przejścia granicznego. Jednakże sytuacja społeczno - ekonomiczna zarówno na polskim, jak i białoruskim nadgraniczu sprawia, że potencjał działalności o charakterze przemytniczym jest tak wysoki, iż na miejsce jednej wyeliminowanej jednostki znajdzie się kilka kolejnych. To nie granica szuka przemytników, a raczej osoby chcące poprawić swoją sytuację materialną szukają granicy.

\section{Bibliografia:}

Berger P. L., Luckmann T. (1983), Społeczne tworzenie rzeczywistości, Warszawa

Badanie obrotu towarów i usług w ruchu granicznym na granicy zewnętrznej Unii Europejskiej na terenie Polski, Główny Urząd Statystyczny, Urząd Statystyczny w Rzeszowie (raporty z badań $\mathrm{z}$ lat 2010-2012)

Jasińska-Kania A. (2006), Neoinstytucjonalizm, [w:] A. Jasińska-Kania, L. Nijakowski, J. Szacki, M. Ziółkowski (wybór i opracowanie), Współczesne teorie socjologiczne, Warszawa

Knight J., Ensiminger J. (1998), Conlifct over Changing Social Norms: Bargaining, Ideology and Enforcement, [w:] M. C. Brinton, V. Nee (red.), The New Institutionalism in Sociology, Stanford

Konecki K. (1992), W japońskiej fabryce. Społeczne i kulturowe aspekty pracy i organizacji przedsiębiorstwa, Łódź

Malikowski M. (1989), Instytucja i instytucjonalizacja jako kategorie teoretyczne socjologii, „Studia Socjologiczne” nr 1(112)

Miszewski K. (2008), Socjolog w kryminale. Więzienie jako nieprzyjazny teren badań, „Studia Socjologiczne" nr 3(178)

Pawlak W. (1993), Instytucje i zmiana instytucjonalna $w$ teorii D. Northa, „Studia Socjologiczne" nr 1(128)

Rottenberg R. (2000), Sitting in a Bar, Studies in Cultures, "Organizations, and Societies" t. 6

Schutz A., (2008), O wielości światów: szkice z socjologii fenomenologicznej, Kraków

Skąpska G. (1999), Neoinstytucjonalizm, [w:] Encyklopedia socjologii, t. 2, Warszawa

Zemło M. (2003), Socjologia wiedzy w tradycji interakcyjno - fenomenologicznej, Lublin 


\section{SUMMARY}

\section{Changes to the Rule of Law and the Process of Institutionalization at the State Border Crossing}

On the basis of a four year long observation at a border crossing point the author will explain the process of institutionalization in specific conditions where social order has been destroyed. The objective of the new law is to restrict the activity of people who use Polish-Belarusian border crossing points and the main purpose of this paper is to show how their behaviors have been influenced by these changes. The behaviors observed during the research explain how a new type of social order can be created, and the author will focus on nine stages which form the process of institutionalization. Expressions such as social action, knowledge, institution and social world are used in a theoretical context. The empirical material gathered during the research is then compared with the discussed theoretical concepts.

\section{Keywords:}

border culture, social world, institutionalization, social construction of reality, social order 